\title{
EXPERIMENTAL ANALYSIS OF THE SIMPLE BENDING STRENGTH OF COMPOSITE STEEL BEAMS OF ROLLED PROFILES WITH SCREWED SPLICE
}

\author{
Welington Vital da Silva ${ }^{1}$, Ronivon Soares Pereira ${ }^{2}$, Cleirton A. Silva Freitas ${ }^{3}$, Valdeir F. de Paula \\ ${ }^{1}$ Doctorate in Structures, Department of Civil Engineering, University of Brasília-UnB. Asa Norte, Campus Darcy \\ Ribeiro, Brasilia, DF, Brazil \\ ${ }^{2}$ Doctorate in Structures, Department of Civil Engineering, University of Brasília-UnB. Asa Norte, Campus Darcy \\ Ribeiro, Brasilia, DF, Brazil \\ ${ }^{3}$ Professor PhD in Civil Engineering, UFCA - Federal University of Cariri, Av. Lieutenant Raimundo Rocha S/N and \\ University City of Juazeiro do Norte, Ceará, CE, Brazil \\ ${ }^{4}$ Professor PhD in Civil Engineering, IFG - Federal Institute of Goiás, Campus of Goiânia: Street 75, $n^{\circ}$ 46, Center, \\ Goiânia GO, Brazil
}

\begin{abstract}
In the construction of any type of building it is necessary to use the connection between the elements, so that the structural engineers make several checks so that there is no collapse in this union. In this sense, this paper presents the experimental study of support capacity of beams supported by steel profiles of laminated section I of type W $250 \times 22.3$. The profile studied complies with ASTM A572 grade 50 laminated on parallel guides with two symmetry axes. Thus, seven prototypes with different screw points were developed along the metal profile. The seven beams were tested with a length of $3000 \mathrm{~mm}$, with a reference beam. In the remaining six beams changes were made in different positions, varying the number of bolted connections. In addition, a numerical model was developed through the ABAQUS CAE commercial program using the arc length formulation implemented in the program named Riks, the results of the numerical model obtained results close to the experimental one with a 6\% error. In which the beams used were the same as those foreseen in this work, but with ASTM A325 and the screw diameter of $19 \mathrm{~mm}$. All models were subjected to simple tensile stress at rupture, where vertical displacements were measured relative to displacements and specific twist deformations of the steel. The bonding bundles withstood the simple bending tests, without the rupture of the high strength bolts. The main contribution of this work was to show that the beams with bolted connections with the specifications described in this work can be used as structural elements, as well as withstand the required design.
\end{abstract}

Keywords: - Beam, Steel, Screw Connections, Laminate, Profile, Single-Fold

\section{INTRODUCTION}

Brazil is one of the main producers of iron ore in the world because its reserves are of high quality and are capable of supplying the national market and generate exportable surpluses. According to the Brazilian Steel Institute (IAB), its installed capacity is 50.4 million tons of crude steel per year. In Brazilian mining, there is a predominance of the production of metallic minerals with $70 \%$, followed by nonmetallic minerals with $29.6 \%$ and finally with gem and diamonds in the house of $0.4 \%$. In some mineral products, Brazil is the largest exporter, as in the cases of iron ore and niobium alloys, and in others, it is among the largest producers such as bauxite, magnesite, phosphate rocks, kaolin, and gold.

The world's reserves of iron ore are estimated at 340 billion tons. The largest reserves are located in the following countries: Ukraine (20\%), Russia (16.5\%), China (13.5\%), Australia (13.2\%) and Brazil (9.8\%).
In this context, Brazil reached the apex of steel production in 2011, mainly due to the major sporting events held in Brazil, namely: FIFA World Cup in 2014 and Olympic Games of the COE in the year 2016. Twelve an Olympic center, modernization of airports, as well as infrastructure for urban mobility.

In this way, the use of metal profiles in the construction has increased mainly due to the advantages that the use of this system provides.

The quality and structural safety of the splices in the rolled profiles must meet the standards required by NBR 8800 (ABNT, 2008) (Steel Structures and Mixed Steel Structures and Concrete)[2]. These profiles have great applicability in large structures and their use is increasing in structures with these characteristics. 
However, the bond between the metal profiles is the weakest point of the system must be carefully checked every possibility of collapse.

When connecting between two structural steel members, which may be between Beam-Beam, Beam-Pillar, PillarPillar and Foundation Pillar, it is essential that this connection, firstly, guarantees the safety of the building. Structural projects must faithfully follow the recommendations of the standards on the subject, as these recommend a minimum resistance of the connections as security measures. Hence the importance of carrying out this study, since the connections between the elements directly influence the safety and the carrying capacity of the building.

\section{OBJECTIVE}

The objective of this work was to analyze the resilient capacity of bi-supported steel beams in Section I laminated sections of type W 250 × 22.3 ASTM A572 50 degree laminates of parallel flaps with two symmetry axes, being joined by high strength bolts, these models were requested by simple bending efforts in order to obtain the flexing of the part.

In addition, electrical strain gauges were installed in the joint to verify the deformation of the bonding plate between the profiles and to evaluate if the splices influence the flexural strength, as well as in the matter of the boundary states of lateral buckling with local twisting and buckling of the core and the profile.

Finally, it is also possible to compare the results obtained in the tests of the beams through the numerical model obtained from the modeling in ABAQUS using non-linear analysis through arc length. The experimental model was executed in the Structures Laboratory of the Federal University of Goiás by the Post-Graduate Program in Civil Engineering in the area of concentration in Structures CMEC-UFG near the capital of Brazil.

\section{LITERATURE REVIEW}

Several works were developed with the purpose of analyzing the influence of the bonds in the behavior of metallic beams subjected to the simple bending stresses. Among some researchers, we can cite CARDOSO (2003) [3], SILVA (2007) [4], ALMEIDA (2009) [5], VIEIRA(2010) [6] and PEREIRA (2014) [7].

Cardoso (2003) [3], carried out the study of the behavior of metallic beams with a "box" composite section, made up of profiles formed in the cold, with welded seams (coated electrode), submitted to simple bending. It was verified that in the welded beams there was an increase in stiffness, decrease in maximum arrow and ductility.

Silva (2007) [4], carried out the study of the behavior of metallic beams in welded profile type "I", with welded seams (coated electrode), submitted to simple bending. It was verified that in the welded beams an increase in the resistance and a decrease in the maximum arrow occurred.

Almeida (2009) [5], carried out an experimental analysis of cold-formed profile beams composed of two reinforced $U$ profiles, with welded seams (coated electrode), subjected to simple bending. It was found that the number of splices 1, 2 or 3 did not significantly influence the strength of the beams.

Vieira (2010) [6], carried out an experimental analysis of "I" section beams composed of cold formed profiles with welded seams (MIG), submitted to simple bending. It was verifiedthat the presence of the weld, so little its positioning, had a significant influence on the strength of the beams.

Pereira (2014) [1] carried out a study that had as objective to analyze the resistant capacity of simple flexion of bisupported beams in steel with bolted seams. The steels used in the manufacture of the studied beams were: Gerdau Profile Steel Laminated mines with parallel flanges of type W 250 x 22.3 ASTM-A572, Gerdau Steel Mine type ASTM-A36 and ASTM-A325 high strength 3 / 4x2 screws ", Eight beams with a length of 3,000 $\mathrm{mm}$ were made by varying the position of the connections, the same used in this research according to Table 2 . The beams had no lateral containment in the supports. It was verified that the beams with screw connections showed vertical displacements three times greater than the disconnected beams, due to the accommodation of the load between screws, connecting plates and profiles, proving a greater rigidity of the beams without connections, the screws or in the connection plates and no beam broke through the steel. The number of bonding was not a collapsing factor for the beams. It concluded that bolted beams are sturdy and thus can be used by metal frame designers as one more option.

\section{METHODOLOGY}

This paper describes the methodology of the steel characterization tests and the determination of the metal beams subjected to simple bending. The rolled metal profiles in the preparation of the tested beams were obtained by cutting $3000 \mathrm{~mm}$ long pieces. The steel characterization tests were completed at the Material Resistance Laboratory of the Pontifical Catholic University of Goiás (PUC-GO). The tests of the beams subjected to the flexion were carried out in the Structures Laboratory of the School of Civil and Environmental Engineering of the Federal University of Goiás (EECA / UFG). Manufacturers of laminated steel sheet with profile lamination W $250 \times 22,3$ ASTM-A572 with specifications according to ABNT NBR 7007 (ABNT, 2011) (Hot and cold rolled carbon steel for structural use, sheet steel ASTM A-36 and welded connections with total penetration welding MIG (Metal Inert Gas). 


\subsection{Characterization of Steel}

To determine the mechanical properties of the steel and the weld used, specimens were removed from the table plates and the profile core; side containment and rigidity test bodies. All specimens were submitted to tensile tests. In these tests the values of the resistance to the steel flow (fy), the tensile strength of the steel (fu) and the elongation of the test pieces after the tests $(\Delta \mathrm{l})$ were obtained. The procedures used in the tensile tests are prescribed in the standard NBR ISO 6892-1 (ABNT, 2013) (Metallic materials: Test of traction) and the results are presented in the item5. The elongation was measured on a measurement basis of $80 \mathrm{~mm}$. The nomenclature used to identify the specimens is shown in Table 1.

Table -1: Nomenclature legend

Nomenclature of specimens for characterization of steel and weld.

\begin{tabular}{|c|c|c|}
\hline Proof body & Quantity & welded seam \\
\hline PBS & 3 & No \\
\hline PBTT & 3 & No \\
\hline PBTB & 3 & No \\
\hline PBCS & 3 & No \\
\hline PBSBW & 3 & Yes \\
\hline PBTTBW & 3 & Yes \\
\hline PBTBBW & 3 & Yes \\
\hline
\end{tabular}

PBS = Proof body plate soul

PBTT = Proof body plate table top

PBTB = Proof body plate table bottom

PBCS = Proof body plate containment side and stiffening

PBSBW = Proof body plate soul with board welded

PBTTBW = Proof body plate table top with board

welded

\section{PBTBBW = Proof body plate table bottom with board} welded

The specimens were removed from three steel plates prior to the assembly operation (virgin steel), $6.30 \mathrm{~mm}$ thick (lateral containment plate and stiffening), $5.80 \mathrm{~mm}$ (core plate) and 6, $90 \mathrm{~mm}$ (table top). The nominal dimensions of these welded and non-welded bodies are shown in Figure 1.

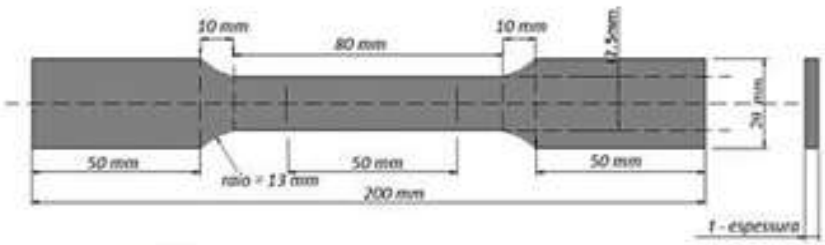

(a) Corpos de prova sem emendas

Proofbody seamless

Fig 1: Dimension of tensile test specimens

\subsection{Characteristics of the Models Tested}

For the development of this research, seven beams with 3,000 $\mathrm{mm}$ long were composed of rolled Gerdau steel mine profiles with parallel flaps of type W 250 x 22.3 ASTMA572 with the height of $250 \mathrm{~mm}$, thickness of the plate of the $5,8 \mathrm{~mm}$ and thickness of the top of $6.9 \mathrm{~mm}$. In all the beams containing connections, bolted connections with high resistance screw were used in order to prevent lateral displacement.

For the execution of the tests of simple bending of the metal beams in laminated profile with the section, I in this article was used gantry in metallic structure with the slab of reaction. The nomenclature of the analyzed models and the dispositions of the amendments were the same ones defined by Pereira (2014), as shown in Table 2. Figure 2 presents each prototype of the beam tested.

Table 2: Model legend

\begin{tabular}{|l|l|}
\hline \multicolumn{2}{|c|}{ Nomenclature of the models tested } \\
\hline BR & Beam reference seamless. \\
\hline B1CB & $\begin{array}{l}\text { Beam with a Connection Bolted 1000mm from the } \\
\text { right support. }\end{array}$ \\
\hline B1CL & $\begin{array}{l}\text { Beam with a Connection bolted to 1000mm from } \\
\text { the Left support. }\end{array}$ \\
\hline B1CMS & $\begin{array}{l}\text { Beam with a bolted connection in the Middle of } \\
\text { the span and stiffeners at 750 mm from the two } \\
\text { Supports with stiffening. }\end{array}$ \\
\hline B1CM & $\begin{array}{l}\text { Beam with screw connection in the middle of the } \\
\text { span. }\end{array}$ \\
\hline B2C & $\begin{array}{l}\text { Beam with two Connections bolted to 1000 mm of } \\
\text { the support. }\end{array}$ \\
\hline B3C & $\begin{array}{l}\text { Beam with three bolted Connections: one in the } \\
\text { middle of the span and two at 750 mm from the } \\
\text { two supports }\end{array}$ \\
\hline
\end{tabular}

3000

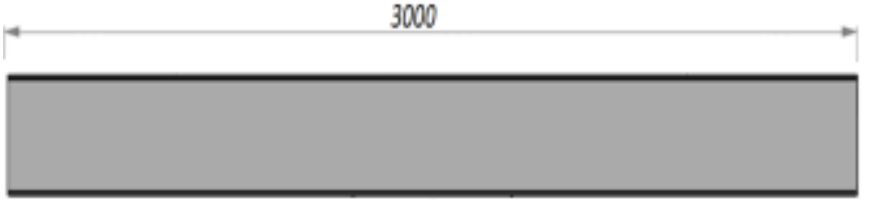

Beam BR

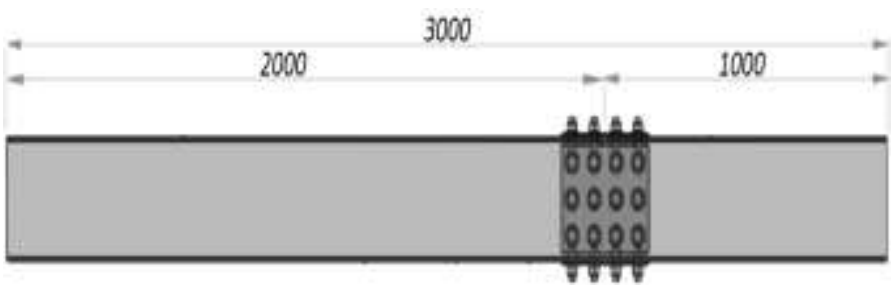

Beam B1CB 


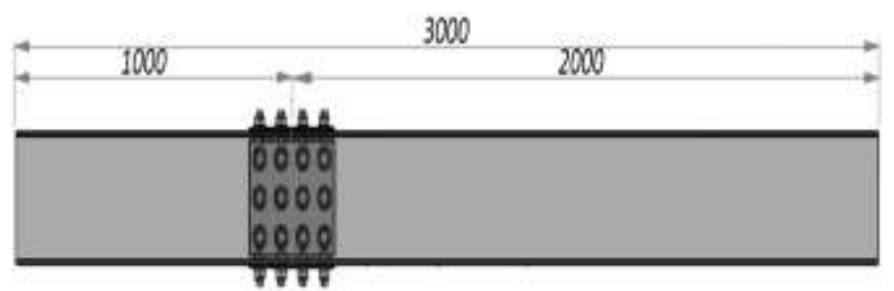

Beam B1CL

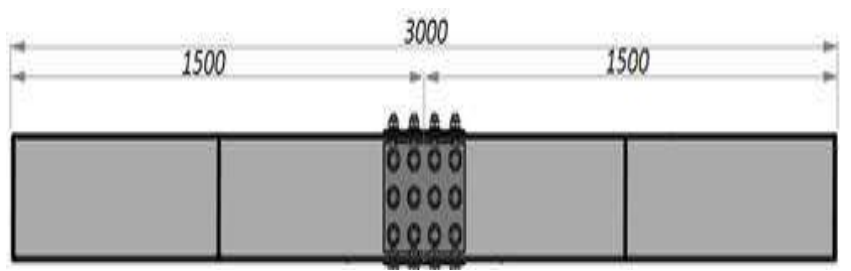

Beam B1CMS
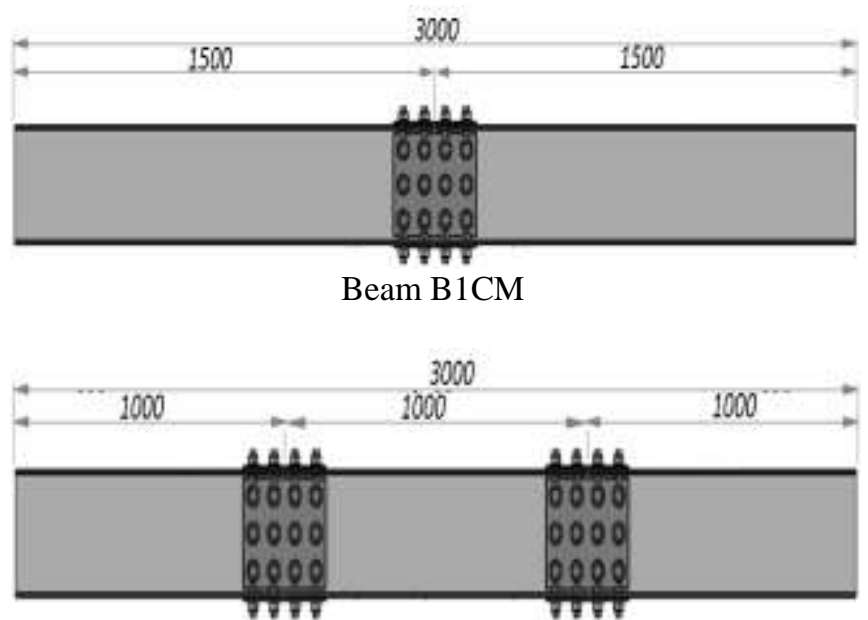

Beam B2C

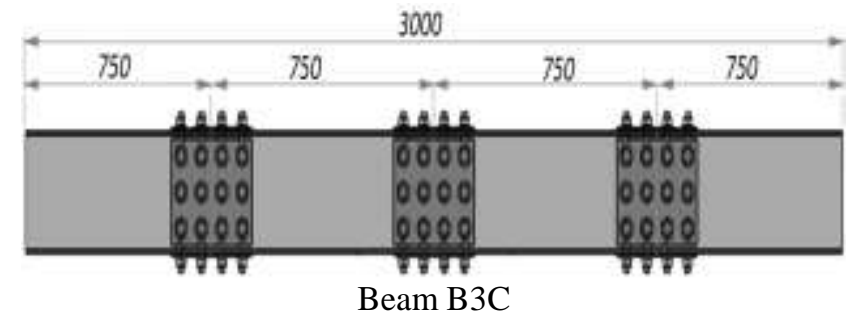

Fig 2: Illustration of the models tested

\subsection{Instrumentation}

Instrumentation precedes testing. Thus strain gates with electric resistance and data acquisition system of the HBM brand were used. Subsequently, the tests were constructed using EXCEL software to measure steel deformations. The preparation of the surface of the metal profiles was used isopropyl alcohol and neutral detergent. The fixation of the strain gates was applied plastic adhesive type cyanoacrylate. In all the beams electrical extensometers were used.
Linear Variable Differential Transformer deflectometer was used to determine the deflection of the prototypes and lateral buckling.

\subsection{Test Scheme}

The static pattern of the beams simulates a bi-supported beam, where each beam tested had a total length of 3000 $\mathrm{mm}$, in which a gap of $75 \mathrm{~mm}$ was left between the axis of the support and the end of the beam, thus, between the supports were $2850 \mathrm{~mm}$. Figure 3 shows a schematic test system of the beams

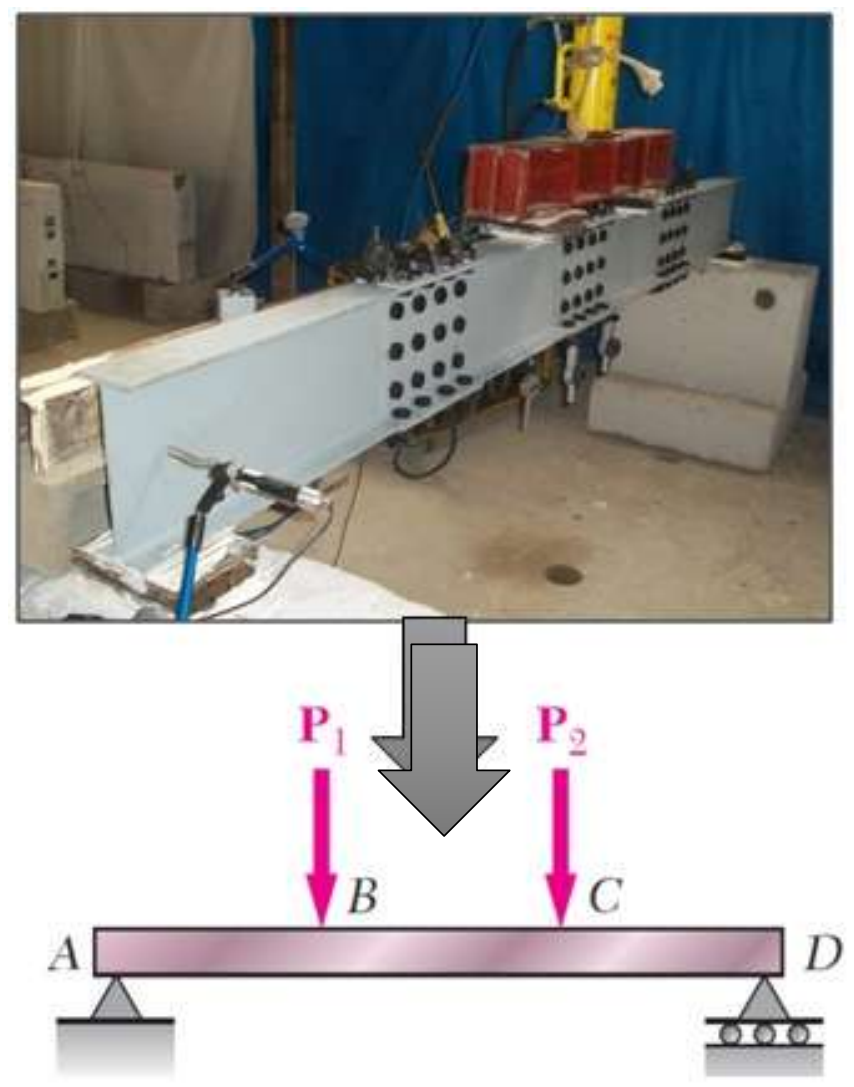

Fig 3: Scheme of application of forces

Support devices were used consisting of metal sheets and steel cylinders simulating the support of the 1st and 2nd genre. For the application of the concentrated load, a transition beam supported on the beam was used, this to obtain a division of the intensity of the force $\mathrm{P}$ applied in two forces equal to $\mathrm{P} / 2$. The load was applied with the help of hydraulic actuator of the brand (Yellow Power)with a capacity of $500 \mathrm{kN}$, and its intensity was verified by a load cell positioned between the hydraulic actuator and the reaction beam. To read the deformations of all extensometers, the AGILENT Bench Link Data Logger Model 34970A data collection equipment was used.

After the final positioning of the beam, comparator clocks were installed to measure the vertical displacements. Watches with a precision of $0.01 \mathrm{~mm}$ and a maximum reading of $50 \mathrm{~mm}$ were used. In order to verify the lateral 
displacement of the upper table and the rotation of the cross section in the beam, LVDTs (linear variable differential transformer) were installed in the core of the beam at 170 $\mathrm{mm}$ from each end.As shown Figure 4.

The assembling method of the test was developed so that all the tests were standardized and divided into the following sequence of steps: installation of the support apparatus, positioning of the beam, installation of the bearings supporting the transmission beam, positioning of the transmission beam, positioning hydraulic actuator, load cell positioning, plumb check; marking and positioning of measuring devices. Figure 5 illustrates the entire experimental apparatus.

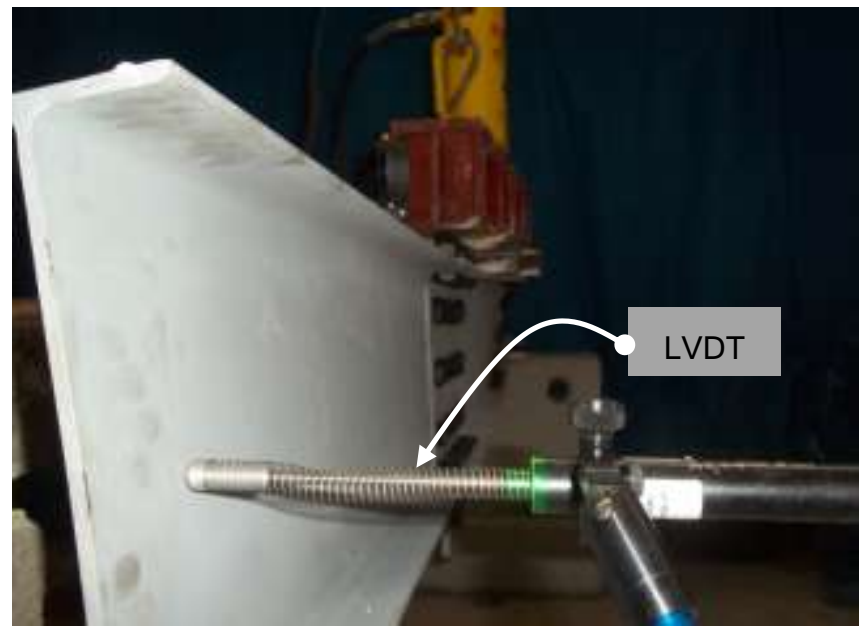

Fig 4: LVDT used in beam

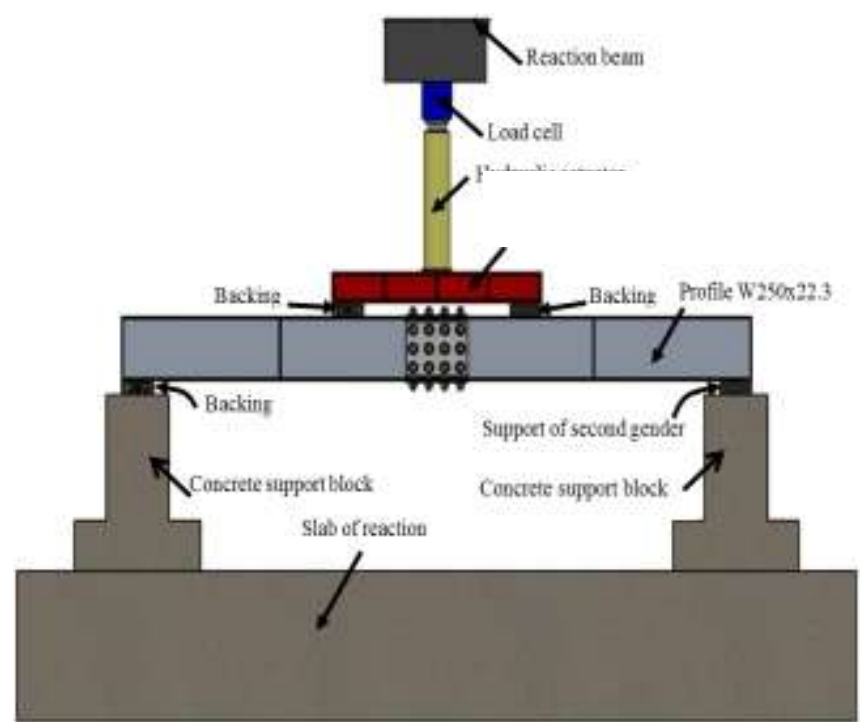

Fig 5: Illustration of the assembled scheme for the testing of beams models.

\section{RESULTS AND DISCUSSION}

The Table 3 shows the mechanical properties of the ASTMA572 grade 50 profile steel, the ASTM-A36 side containment and stiffening plate and the MIG welding electrode used.
Table 3: Property of materials

\begin{tabular}{|l|l|l|l|l|}
\hline \multicolumn{6}{|l|}{ Mechanical properties of steel and weld } \\
\hline Specif. & $\begin{array}{l}\text { Equi } \\
\text { v. } \\
\text { NBR } \\
7007: \\
2011\end{array}$ & $\begin{array}{l}\text { Lim. } \\
\text { Flowminimu } \\
\text { m (Mpa) }\end{array}$ & $\begin{array}{l}\text { Lim. } \\
\text { strengthminimu } \\
\text { m (Mpa) }\end{array}$ & $\begin{array}{l}\text { Min } \\
\text { elong. } \\
\text { afterru } \\
\text { p. }(\%)\end{array}$ \\
\hline $\begin{array}{l}\text { ASTM } \\
\text { A36 }\end{array}$ & $\begin{array}{l}\text { MR } \\
250\end{array}$ & 250 & $400-560$ & 23 \\
\hline $\begin{array}{l}\text { ASTM } \\
\text { A572 }\end{array}$ & $\begin{array}{l}\text { AR } \\
350\end{array}$ & 345 & 450 mín. & 21 \\
\hline ASME & & 400 & 480 & 22 \\
AWS & & & & \\
\hline
\end{tabular}

The Figure 6 shows the voltage vs. deflection graph for the test pieces of the top table without and with welded seam.

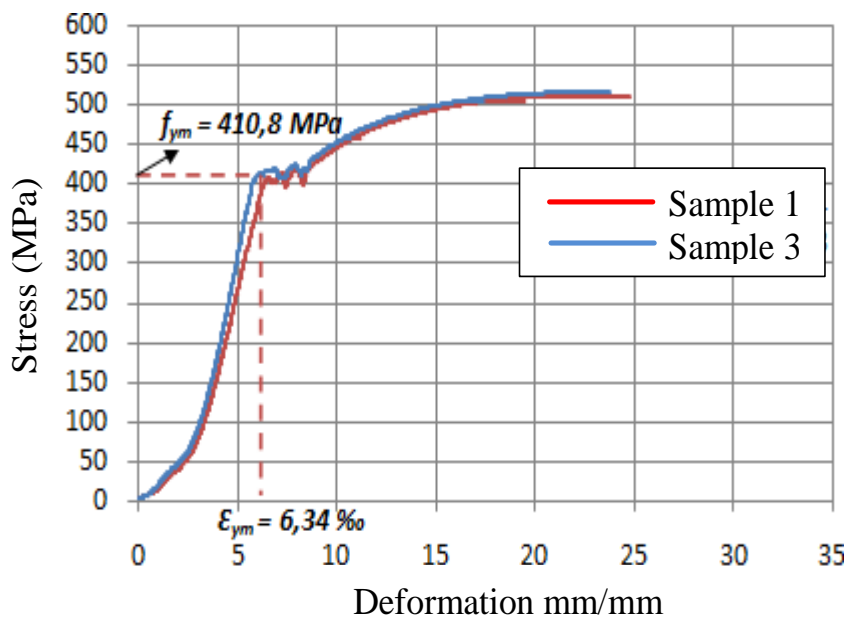

(a) PBTT

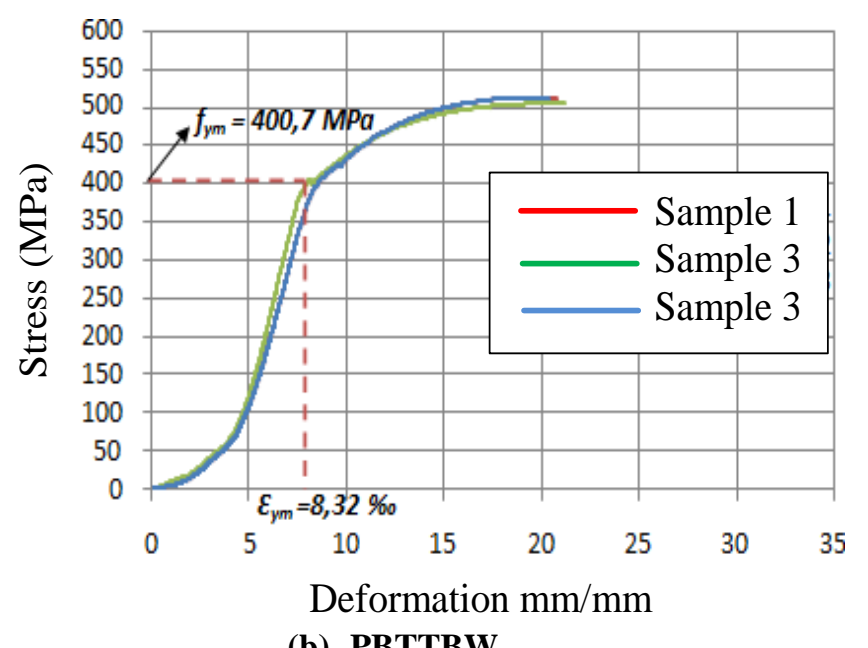

(b) PBTTBW

Fig 6: Graph Voltage x Deformation for upper table test bodies

The table 4 presents the results of the tensile tests on the specimens for the characterization of the steel and the weld used in this paper. A procedural error occurred in the test of 
sample 2 of the CPMS (Upper Board Testing Body). The ruptures in the specimens with welded seams occurred outside the region of the weld.

The results obtained in the tensile tests for the characterization of the steel in relation to the yield limit, resistance limit and rupture deformation, table test specimens, core and lateral containment and stiffening were above the minimum established by NBR 7007 (ABNT, 2011). For the characterization of the weld, the results found were also above the minimum established for the type of weld used. The steel of the test pieces ruptured before the weld and already with values above the minimum established by the norm for the type of electrode used, therefore, the weld had a resistance greater than the standard AWS A5.18 (2005) establishes. The values of rupture deformations of the welded specimens were smaller than those of the seamless specimens, which proves that the weld caused a reduction in the ductility of the welded weld body. Therefore, the values found in the tensile tests are in accordance with those established by the standards inforce on the subject.

Table 4: Results obtained in the characterization tests of steel.

\begin{tabular}{|c|c|c|c|c|c|c|c|c|c|c|}
\hline proof body & $\begin{array}{l}\text { Type of } \\
\text { Steel }\end{array}$ & 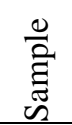 & $\begin{array}{c}\mathrm{f}_{\mathrm{y}} \\
(\mathrm{MPa})\end{array}$ & $\begin{array}{l}\varepsilon_{\mathrm{y}} \quad(\mathrm{mm} / \\
\mathrm{m})\end{array}$ & $\begin{array}{c}\mathrm{f}_{\mathrm{u}} \\
(\mathrm{MPa})\end{array}$ & $\begin{array}{l}\varepsilon_{\mathrm{u}} \\
(\mathrm{mm} / \mathrm{m})\end{array}$ & $\begin{array}{l}\mathrm{m} \\
\mathrm{YPa})\end{array}$ & $\begin{array}{l}\begin{array}{l}\text { Eym } \\
(\mathrm{mm} / \\
\mathrm{m})\end{array} \\
\end{array}$ & $\begin{array}{c}\text { fum } \\
(\mathrm{MPa})\end{array}$ & $\begin{array}{l}\text { Eum }(\mathrm{mm} / \\
\mathrm{m})\end{array}$ \\
\hline PBCS & $\begin{array}{l}\text { 5TM } \\
36\end{array}$ & $\begin{array}{l}1 \\
2 \\
3\end{array}$ & $\begin{array}{l}318,11 \\
298,07 \\
288,76\end{array}$ & $\begin{array}{l}5,51 \\
5,34 \\
5,39\end{array}$ & $\begin{array}{l}422,96 \\
420,50 \\
418,12\end{array}$ & $\begin{array}{l}33,72 \\
32,61 \\
34,80\end{array}$ & $\begin{array}{l}301,6 \\
5\end{array}$ & 5,41 & 420,52 & 33,71 \\
\hline PBTT & $\begin{array}{l}\text { ASTM } \\
\text { A572 }\end{array}$ & $\begin{array}{l}1 \\
2 \\
3\end{array}$ & $\begin{array}{l}408,05 \\
--- \\
413,63\end{array}$ & $\begin{array}{l}6,56 \\
--- \\
6,12\end{array}$ & $\begin{array}{l}511,00 \\
--- \\
515,07\end{array}$ & $\begin{array}{l}24,72 \\
--- \\
23,77\end{array}$ & $\begin{array}{l}410,8 \\
4\end{array}$ & 6,34 & 513,03 & 24,24 \\
\hline PBTB & $\begin{array}{l}\text { ASTM } \\
\text { A572 }\end{array}$ & $\begin{array}{l}1 \\
2 \\
3\end{array}$ & $\begin{array}{l}414,68 \\
413,51 \\
405,50\end{array}$ & $\begin{array}{l}6,39 \\
6,99 \\
7,49\end{array}$ & $\begin{array}{l}527,03 \\
527,03 \\
488,23\end{array}$ & $\begin{array}{l}23,53 \\
25,26 \\
23,91\end{array}$ & $\begin{array}{l}411,2 \\
3\end{array}$ & 6,95 & 514,09 & 24,23 \\
\hline PBS & $\begin{array}{l}\text { ASTM } \\
\text { A572 }\end{array}$ & $\begin{array}{l}1 \\
2 \\
3\end{array}$ & $\begin{array}{l}402,37 \\
376,81 \\
405,55\end{array}$ & $\begin{array}{l}6,90 \\
3,36 \\
6,00\end{array}$ & $\begin{array}{l}485,04 \\
455,19 \\
480,05\end{array}$ & $\begin{array}{l}23,77 \\
23,96 \\
24,72\end{array}$ & $\begin{array}{l}394,9 \\
1\end{array}$ & 5,42 & 473,42 & 24,15 \\
\hline PBTTBW & $\begin{array}{l}\text { ASTM } \\
\text { A572 }\end{array}$ & $\begin{array}{l}1 \\
2 \\
3\end{array}$ & $\begin{array}{l}401,09 \\
404,23 \\
396,68\end{array}$ & $\begin{array}{l}8,53 \\
8,10 \\
8,33\end{array}$ & $\begin{array}{l}511,24 \\
504,03 \\
512,06\end{array}$ & $\begin{array}{l}20,82 \\
21,20 \\
20,35\end{array}$ & $\begin{array}{l}400,6 \\
6\end{array}$ & 8,32 & 509,11 & 20,79 \\
\hline PBTBBW & $\begin{array}{l}\text { ASTM } \\
\text { A572 }\end{array}$ & $\begin{array}{l}1 \\
2 \\
3\end{array}$ & $\begin{array}{l}402,01 \\
416,31 \\
416,89\end{array}$ & $\begin{array}{l}6,10 \\
8,89 \\
7,29\end{array}$ & $\begin{array}{l}502,29 \\
534,13 \\
497,06\end{array}$ & $\begin{array}{l}20,45 \\
22,37 \\
22,35\end{array}$ & $\begin{array}{l}411,7 \\
3\end{array}$ & 7,42 & 511,16 & 21,72 \\
\hline PBSBW & $\begin{array}{l}\text { ASTM } \\
\text { A572 }\end{array}$ & $\begin{array}{l}1 \\
2 \\
3\end{array}$ & $\begin{array}{l}395,19 \\
393,39 \\
402,09\end{array}$ & $\begin{array}{l}4,03 \\
7,04 \\
6,61\end{array}$ & $\begin{array}{l}495,27 \\
495,13 \\
502,04\end{array}$ & $\begin{array}{l}16,37 \\
21,59 \\
20,46\end{array}$ & $\begin{array}{l}396,8 \\
9\end{array}$ & 5,89 & 497,48 & 19,47 \\
\hline \multicolumn{11}{|c|}{$\begin{array}{l}\text { PBCS = Proof body plate containment side and stiffening } \\
\text { PBTT = Proof body plate table top } \\
\text { PBTB = Proof body plate table bottom } \\
\text { PBS = Proof body plate soul } \\
\text { PBTTBW = Proof body plate table top with board welded } \\
\text { PBTBBW = Proof body plate table bottom with board welded } \\
\text { PBSBW = Proof body plate soul with board welded } \\
\text { Fy = Resistance to flow; fym= Medium flow resistance; } 8 y=\text { Flow start deformation; \&ym= Mean flow onset deformation; fu = Breaking } \\
\text { strength; fum = Medium breaking strength; } \varepsilon u=\text { Final deformation; \&um = Mean final deformation. }\end{array}$} \\
\hline
\end{tabular}

\subsection{Load and Rupture Mode}

The table 5 shows the results of the last estimated loads and the last loads of tests, test bending moments, bending moments of calculation according to NBR 8800 (ABNT, 2008) and failure modes and of the stud bolted joists made by Pereira (2014) [1].
The Figure 7 (a) shows the bolted V2L beam; part (b) presents the welded V2L beam, both after the simple bending test. In this figure the modes of rupture of the two beams are indicated. 

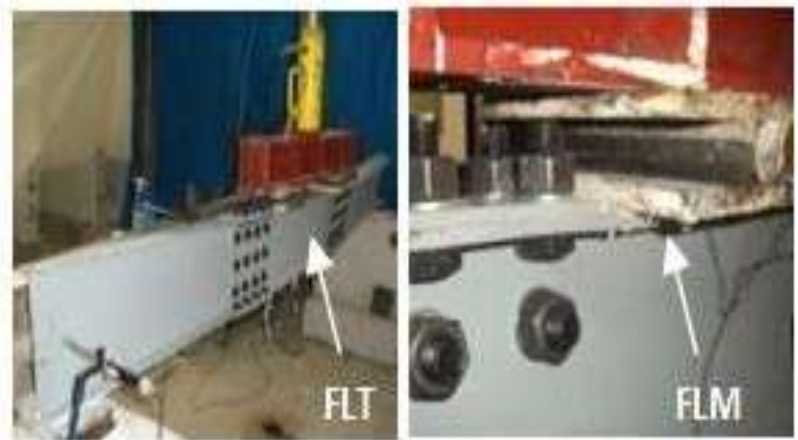

Beam bolted prototypic V2L

Fig 7: Modes of rupture of V2L beams with screwed and welded connections.

The results in Table 5 show that all stud bolted joists had ultimate loads between $86 \%$ and $99 \%$ of the estimated design load. The fact that the bolted joists resist less than the estimated one was due to the absence of lateral containment in the supports since the reference beam that had lateral containment had a rupture load $16 \%$ higher in comparison with the reference beam that did not have. The positions in which the stiffeners were welded did not influence the increase of the rupture loads of the V1LME beams. The beams with a bolted connection presented rupture loads between 0 and 19\% higher than the estimated calculation load. The beams with two (V2L) and three (V3L) bolted joints presented lower than estimated loads, with $84 \%$ and $92 \%$ of the estimated load, respectively. The non- coplanarity in the region of the weld (see Figure 8), maybe a possible explanation for this fact, due to the instability created and that may have accentuated as the load increased, causing the collapse sooner than expected. But a deeper investigation into this is needed. The test moments of the bolted V2L and V3L beams were lower than the hard times of calculation for the FLT (Torsional buckling), but even so, FLA (Buckling in high) occurred. This fact can be explained by the voltage concentration in the upper table in the two load application areas.

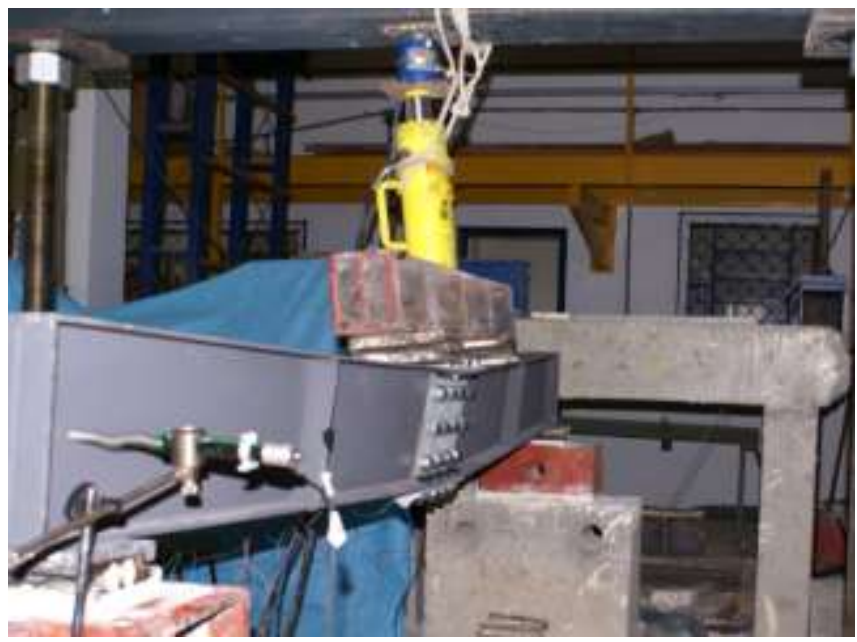

Fig 8: Non-coplanarity region in the V2L and V3L beams.

Table - 5: Results latest loads, bending moments and failure modes of beams with bolted and welded connections

\begin{tabular}{|c|c|c|c|c|c|c|c|c|c|c|c|}
\hline \multirow[t]{2}{*}{ Beam } & \multirow{2}{*}{$\begin{array}{l}\text { Puest } \\
\dot{(k N)}\end{array}$} & \multicolumn{2}{|c|}{$\mathbf{P}_{\mathrm{u}}(\mathbf{k N})$} & \multirow{2}{*}{$\begin{array}{l}\mathbf{P u S c r e}_{\mathbf{u}} \\
\text { W. } \\
\mathbf{P}_{\mathbf{u W e}} \\
\text { 1. }\end{array}$} & \multicolumn{2}{|c|}{$M_{\text {ensaio }}$ (kN.m) } & \multirow{2}{*}{$\begin{array}{l}\mathbf{M}_{\mathrm{Rd}} \mathbf{F L} \\
\mathbf{A} \\
(\mathrm{kN} . \mathrm{m})\end{array}$} & \multirow{2}{*}{$\begin{array}{l}\mathbf{M}_{\mathbf{R d}} \mathbf{F L} \\
\mathbf{M} \\
(\mathbf{k N . m})\end{array}$} & \multirow{2}{*}{$\begin{array}{l}\mathbf{M}_{\mathbf{R d}} \mathbf{F L} \\
\mathbf{T} \\
(\mathrm{kN.m})\end{array}$} & \multicolumn{2}{|c|}{ Failure modes } \\
\hline & & $\begin{array}{l}\text { Scre } \\
\text { w. }\end{array}$ & Weld. & & Scre. & $\begin{array}{l}\text { Weld } \\
\text {. }\end{array}$ & & & & Screw. & Weld. \\
\hline $\begin{array}{l}\text { VREF } \\
*\end{array}$ & 146,7 & 135,0 & 160,0 & 0,84 & 77,3 & 91,6 & 84,0 & 84,0 & 49,2 & $\begin{array}{l}\text { FLM/FL } \\
\mathrm{T}\end{array}$ & FLM/FLT \\
\hline $\begin{array}{l}\text { V1L } \\
\text { M }\end{array}$ & 146,7 & 135,0 & 166,0 & 0,81 & 77,3 & 95,0 & 84,0 & 84,0 & 49,2 & $\begin{array}{l}\text { FLM/FL } \\
\mathrm{T}\end{array}$ & FLM/FLT \\
\hline $\begin{array}{l}\text { V1L } \\
\text { ME }\end{array}$ & 146,7 & 133,5 & 160,0 & 0,83 & 76,4 & 91,6 & 84,0 & 84,0 & 49,2 & $\begin{array}{l}\text { FLM/FL } \\
\mathrm{T}\end{array}$ & FLM/FLT \\
\hline V1LD & 146,7 & 138,0 & 163,0 & 0,85 & 79,0 & 93,3 & 84,0 & 84,0 & 49,2 & $\begin{array}{l}\text { FLM/FL } \\
\mathrm{T}\end{array}$ & FLM/FLT \\
\hline V1LE & 146,7 & 140,0 & 175,0 & 0,80 & 80,1 & 100,2 & 84,0 & 84,0 & 49,2 & $\begin{array}{l}\text { FLM/FL } \\
\mathrm{T}\end{array}$ & FLM/FLT \\
\hline V2L & 146,7 & 145,2 & 123,0 & 1,18 & 83,1 & 70,4 & 84,0 & 84,0 & 49,2 & $\begin{array}{l}\text { FLM/FL } \\
\mathrm{T}\end{array}$ & FLM/FLT \\
\hline V3L & 146,7 & 126,4 & 135,0 & 0,94 & 72,4 & 77,3 & 84,0 & 84,0 & 49,2 & $\begin{array}{l}\text { FLM/FL } \\
\mathrm{T}\end{array}$ & FLM/FLT \\
\hline
\end{tabular}

Pu = Load last test load; Pu est. = Load last estimated calculation for MRd FLM, according to annex G of the

\section{ABNT NBR 8800:2008}

Mensaio $=$ Resistant bending moment of calculation in relation to the tests

MRd FLA , MRd FLM e MRd FLT = Resistant bending moment calculation according to Annex G da NBR

8800:2008, to theFLA, FLM e FLT, respectively.

FLM =Local buckling of the Board; FLA = Local buckling of the Soul; FLT = Torsional lateral buckling 


\subsection{Maximum Vertical Displacements}

The figure 9 shows the positioning of the clocks on all the beams and the vertical displacements of the V1LM beam with bolted connection. The largest vertical displacements were recorded on the R3 watch, on all beams with bolted connections. In the beams

with bolted connections, variations of the positions of the maximum vertical displacements occurred. Table 6 shows the results of the maximum displacements for the service limit state (L / 350 for floor girder), according to Annex C of NBR 8800 (ABNT, 2008).
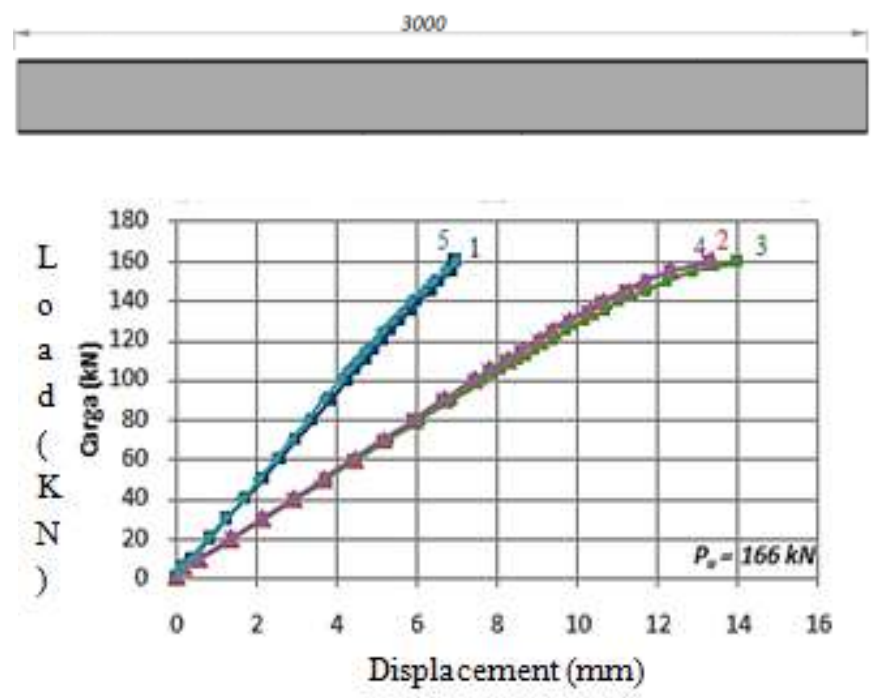

Fig 9: Displacement of prototypes
The figure 10 shows the maximum vertical displacements of tests of beams with screwed connections.

In order to have a more accurate comparison of the vertical displacement of the test with respect to the same load of the beams with welded and bolted connections, the vertical displacement graph for the load of $120 \mathrm{kN}$ as a function of the length for all the beams was plotted, as shown by Figure 11. For this load, the vertical displacements of the beams with bolted connections were superior to those of the beams no connections, which proves a greater rigidity of the bolted connections. This fact can be explained, due to the accommodation between profile, plate and bolts at the time of testing.

Table - 6: Results of displacement

Maximum theoretical and test vertical displacements.

\begin{tabular}{|c|c|c|c|c|c|c|c|c|c|c|}
\hline Beam & \multicolumn{2}{|c|}{$P_{u}(k N)$} & \multirow{2}{*}{$\begin{array}{r}\Delta \text { máxim } \\
\text { o (mm) }\end{array}$} & \multicolumn{2}{|c|}{$\Delta$ teórico $(\mathrm{mm})$} & \multicolumn{2}{|c|}{$\Delta$ ensaio $(\mathbf{m m})$} & \multirow{2}{*}{$\mid \begin{array}{c}\Delta \square \square \square \square \square \\
\square \square \square \square \square \square . \\
\Delta \square \square \square \square \square \\
\square \square \square \square \square .\end{array}$} & \multicolumn{2}{|c|}{ Relógio } \\
\hline & $\begin{array}{c}\text { Paraf } \\
.\end{array}$ & Sold. & & Paraf. & Sold. & $\begin{array}{c}\text { Paraf } \\
\cdot\end{array}$ & Sold. & & $\begin{array}{c}\text { Paraf } \\
.\end{array}$ & Sold. \\
\hline VREF* & 135,0 & 160,0 & 8,57 & 10,5 & 12,4 & 10,6 & 12,6 & 0,84 & R3 & $\mathrm{R} 3$ \\
\hline V1LM & 135,0 & 166,0 & 8,57 & 10,5 & 12,8 & 44,0 & 13,9 & 3,15 & R3 & R3 \\
\hline V1LME & 133,5 & 160,0 & 8,57 & 10,4 & 12,4 & 39,3 & 14,3 & 2,75 & R3 & $\mathrm{R} 3$ \\
\hline V1LD & 138,0 & 163,0 & 8,57 & 9,9 & 12,6 & 28,3 & 13,2 & 2,13 & $\mathrm{R} 2$ & R3 \\
\hline V1LE & 140,0 & 175,0 & 8,57 & 10,6 & 13,5 & 32,5 & 14,8 & 2,19 & $\mathrm{R} 4$ & R3 \\
\hline V2L & 145,2 & 123,0 & 8,57 & 11,0 & 9,3 & 46,2 & 9,7 & 4,72 & $\mathrm{R} 2$ & R3 \\
\hline V3L & 126,4 & 135,0 & 8,57 & 9,8 & 10,4 & 50,6 & 12,0 & 4,18 & R3 & R3 \\
\hline $\begin{array}{l}\text { Pu = Load } \\
\Delta \text { máximo } \\
\text { Displacem } \\
\text { amount of }\end{array}$ & $\begin{array}{l}\text { st test } \\
\text { Maxi } \\
\text { t theo } \\
\text { aximı }\end{array}$ & $\begin{array}{l}\text { ad } \\
\text { m dis } \\
\text { tical ca } \\
\text { displa }\end{array}$ & $\begin{array}{l}\text { ement } \\
\text { lation; } \\
\text { ent }\end{array}$ & saio & ximu & est & $\begin{array}{l}/ 350 \\
\text { cemei }\end{array}$ & $\begin{array}{l}\text { floor gi } \\
\text { ock }=\mathrm{Cl}\end{array}$ & at & $\begin{array}{l}\text { ical }= \\
\text { ed the }\end{array}$ \\
\hline
\end{tabular}




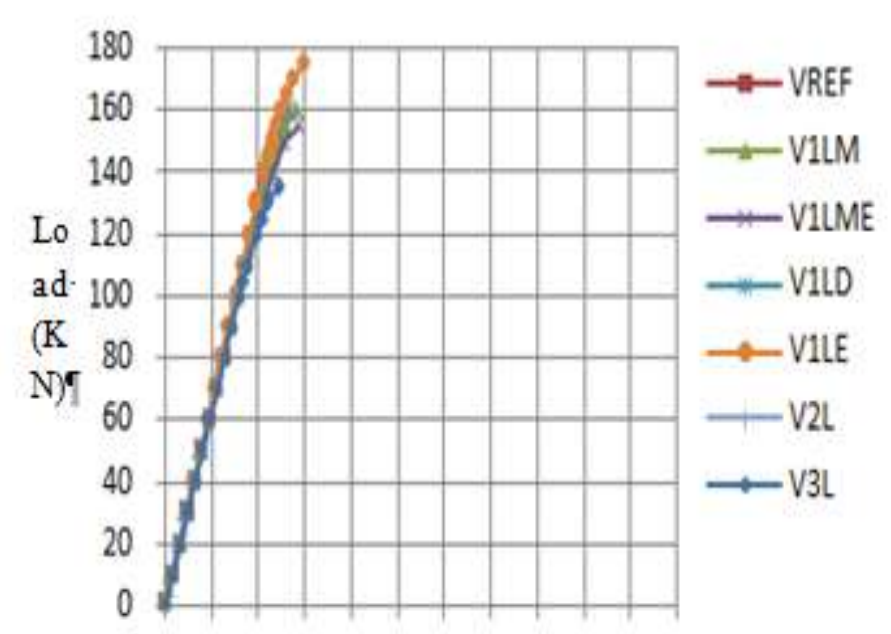

$0 \quad 510152025303540455055$

Displacement $(\mathrm{mm}) \boldsymbol{r}$

(a) Beam with conectionbolted

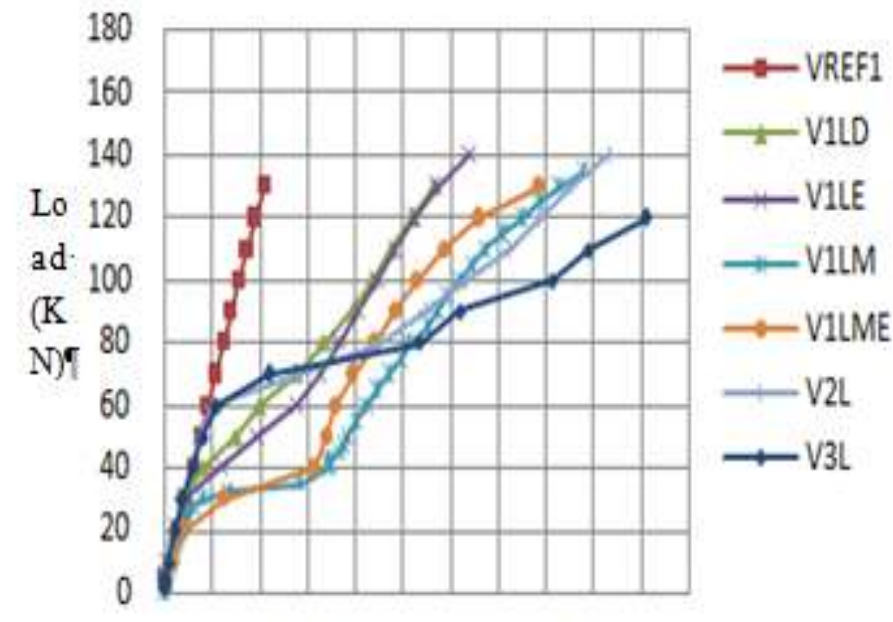

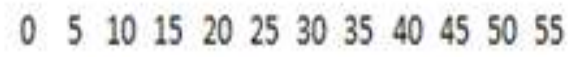

Displacement $(\mathrm{mm}) \Upsilon$

(b) Beam with conectionscrew

Fig 10: Maximum vertical displacements of teste

$$
\text { Cor Length(mm) }
$$

\section{$\begin{array}{lllllll}0 & 500 & 1000 & 1500 & 2000 & 2500 & 3000\end{array}$}

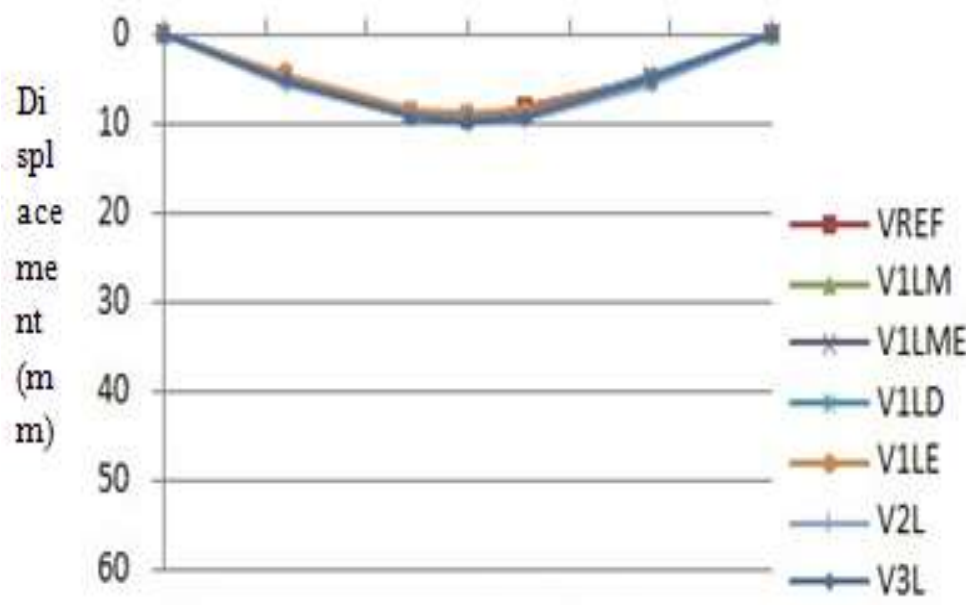

(a) Beam with conectionwelded
Length $(\mathrm{mm})$ ito (mm) $\begin{array}{lllllll}0 & 500 & 1000 & 1500 & 2000 & 2500 & 3000\end{array}$

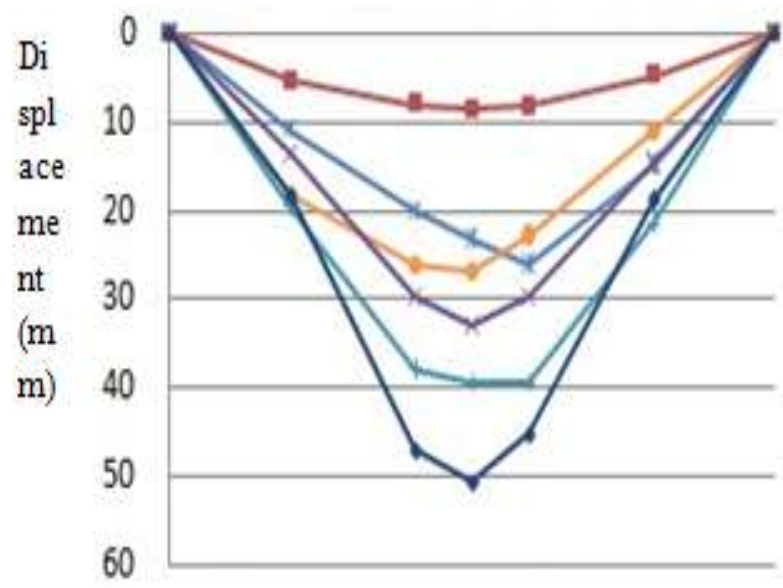

(b) Beam with conectionscrew

Fig 11: Test vertical displacements at load of $120 \mathrm{KN}$ 


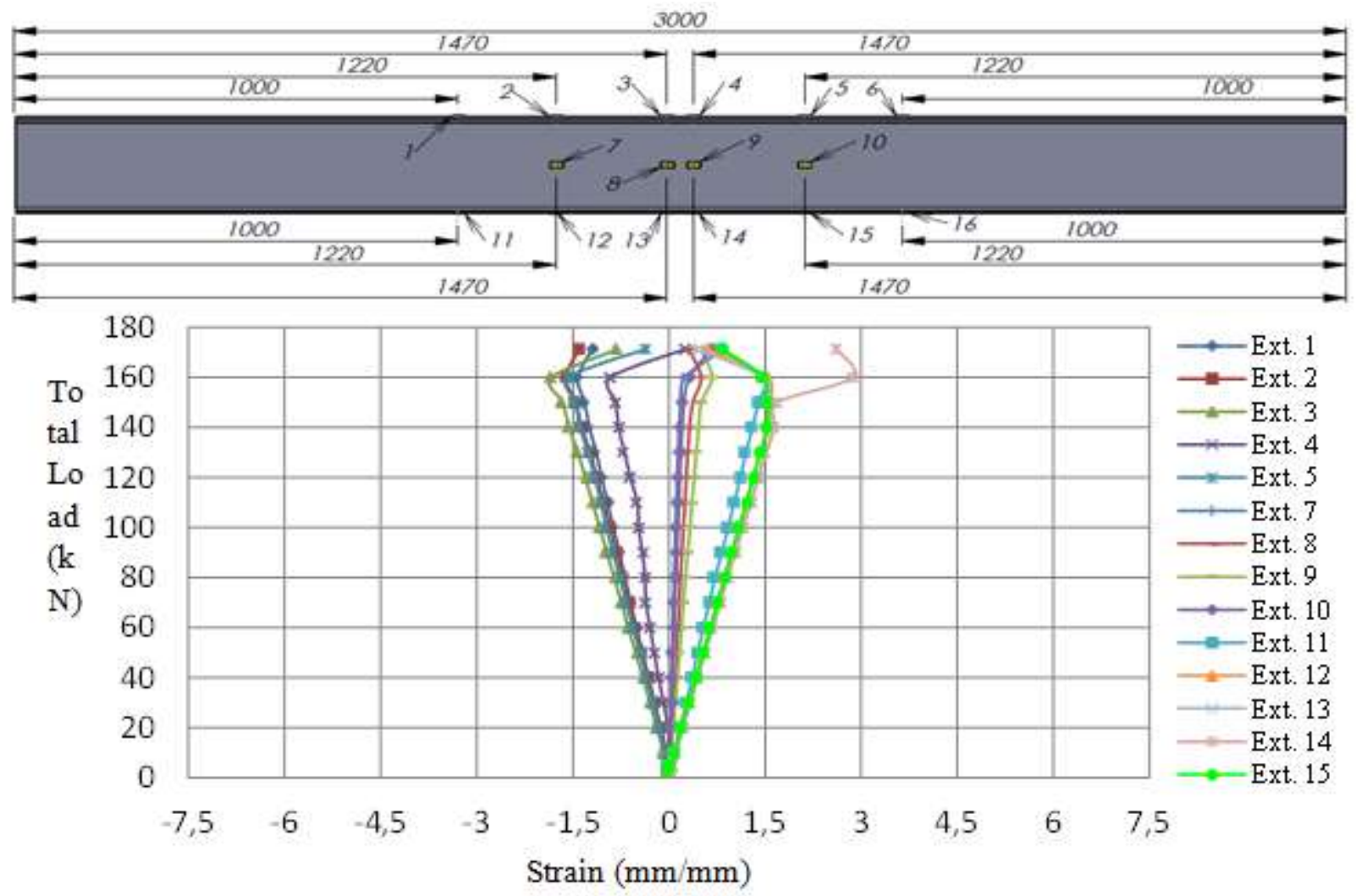

Fig 11: Graphical load versus strain of prototype

\subsection{Model Numeric}

Using the Finite Element Method FEM, a numerical model was developed through the commercial program ABAQUS, the objective was to model the beam tested in order to finish the torsion resistant capacity.The FEmodelwas used for a doubly symmetric I-section beamwith simply supported boundary conditions and subjected to uniform bendingmoment over the span length.Detailed descriptions of the model geometry, meshing and material behavior, the applications of boundary conditions, the loading, initial. The geometry and meshing provides an overview of the FE model developed in this study, together with the relevant the coordinate system in which the Lagrangian $\mathrm{y}$ and $\mathrm{Z}$ axes define the plane of the cross-section and the $\mathrm{X}$-coordinate defines the longitudinal beam axis. Because of the presence of symmetric conditions in terms of geometry, loading and support of the beam, only half of the span were modeled. The four-node shell element with reduced integration S4R was utilized in the modeling. The S4R element is characterized with six degrees of freedom per node, provides an accurate solution to most applications and allows for transverse shear deformation. The element also accounts for finite strain and is suitable for large-strain analysis. Simpson's rule with five integration points is used through the element's thickness.

As the cross sections of the metal profiles are composed of slender parts (flanges or tables and webs), there is a possibility of a great reduction in the resistance of bending structural elements due to lateral and local buckling phenomena. The lateral buckling is a destabilization of the part under flexion due to the compression of the upper table, taking it out of its plane, and traction of the lower table, fixing it, which causes rotation and transverse displacement of the sections of the piece. The local buckling is the destabilization of part of the profile (tables or soul) by the occurrence of folds located punctually along the length. In the Figure12, the two types of buckling are illustrated.

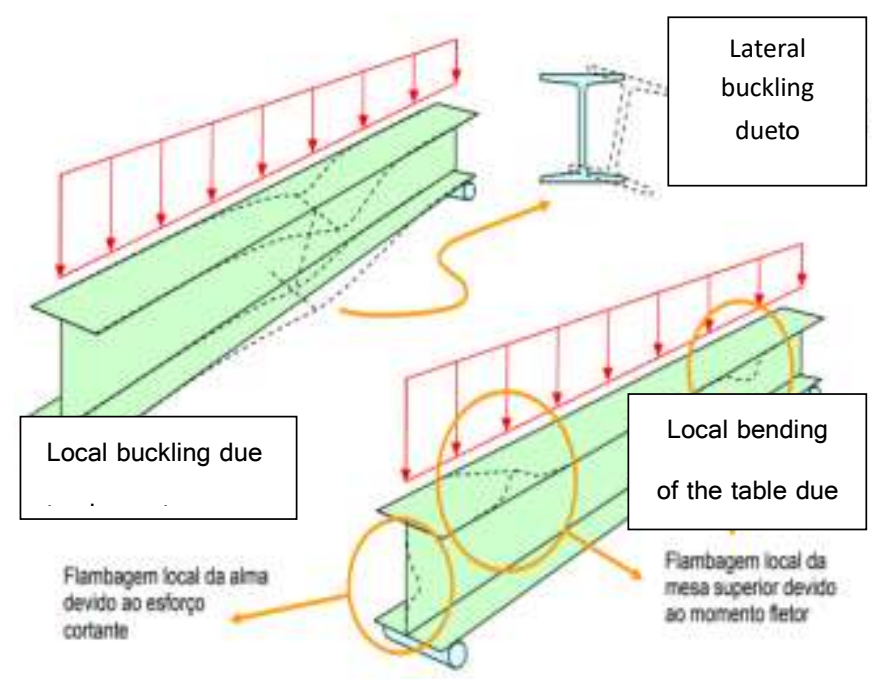

Fig 12: Possibilities of buckling in metallic profile 
These two phenomena, which can easily carry a beam to collapse, can be avoided by some simple measures. Firstly, in order to avoid lateral buckling, the lateral containment of the profile can be carried out, so that there is the impedance of turns and lateral translations.

The Figure12 shows the details of Euler buckling due to instability after bifurcation pointSalokhe, Patil P (2015).

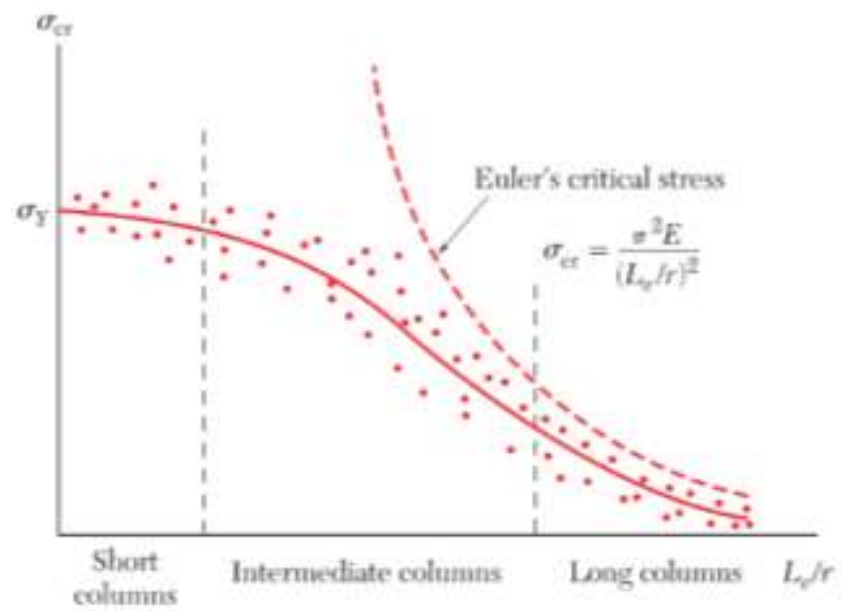

Fig 13: Buckling curve

Figure 14 shows the flowchart used to determine the strength of the laminad profile. The numerical model used the iterative method of arc length, implemented in ABAQUS as Ricks.

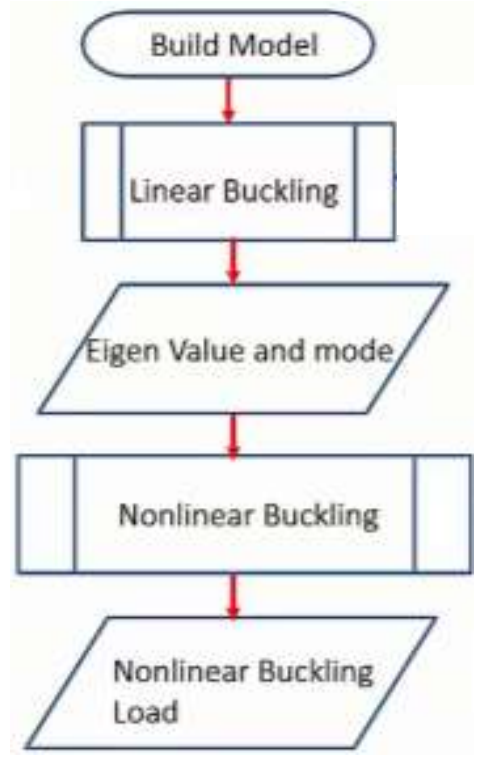

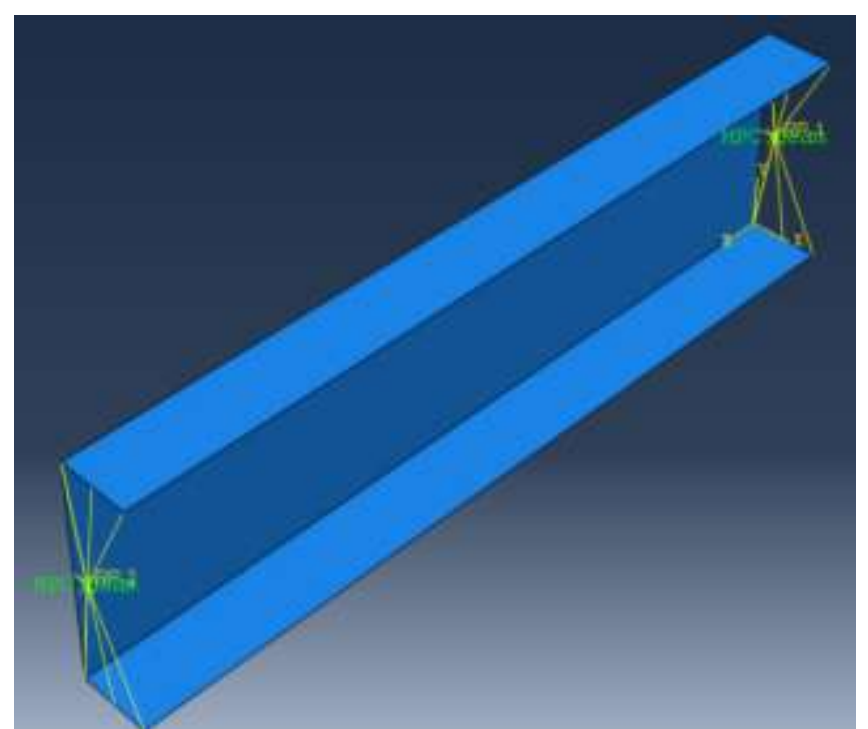

Fig 14: Model in ABAQUSCAE

In model used number of elements is 3240 , nodes is 3369 whit number of nodes defined by the user 3369 , total number of variables in the model 20214. Degrees of freedom plus max no. Of any Lagrange multiplier. Figure 15 shows the details of the modeling
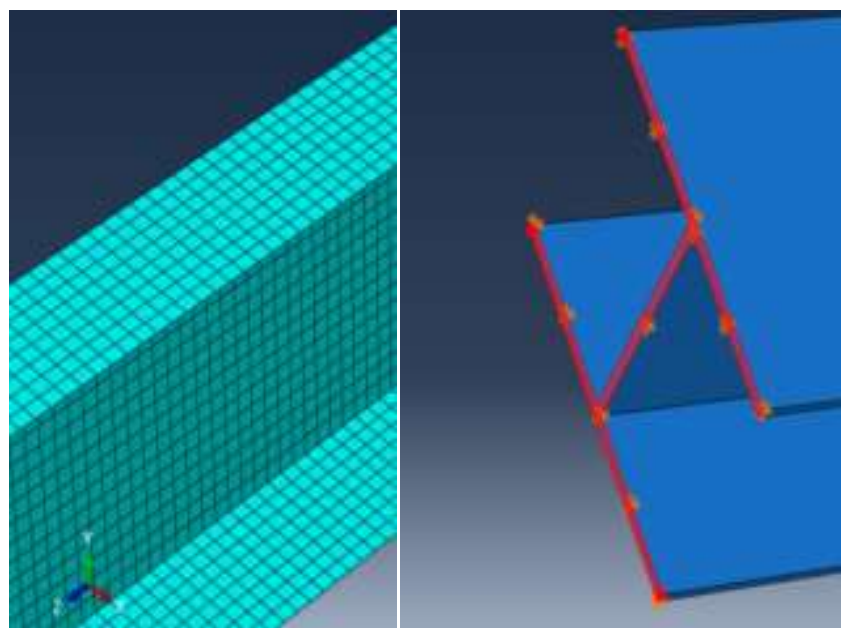

Fig 15: Element details and boundary conditions.

The results of the numerical model were very close to the results of the experimental tests, Figure 15 presents the values of six eigenvectors, however, in the physical models the structure presents only the first module. 


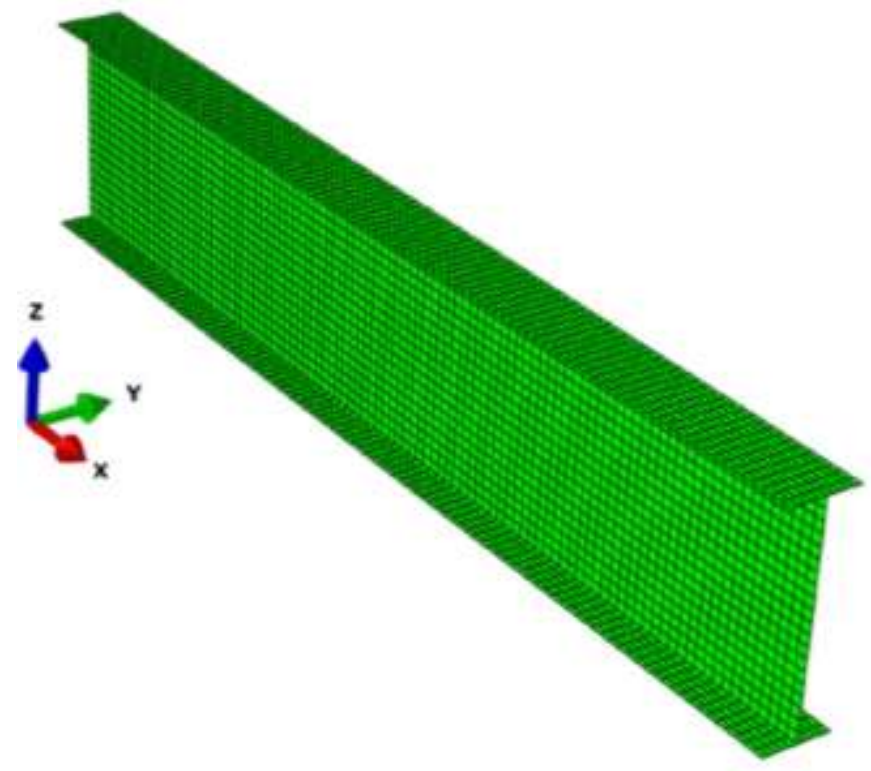

(a) Model in ABAQUS CAE

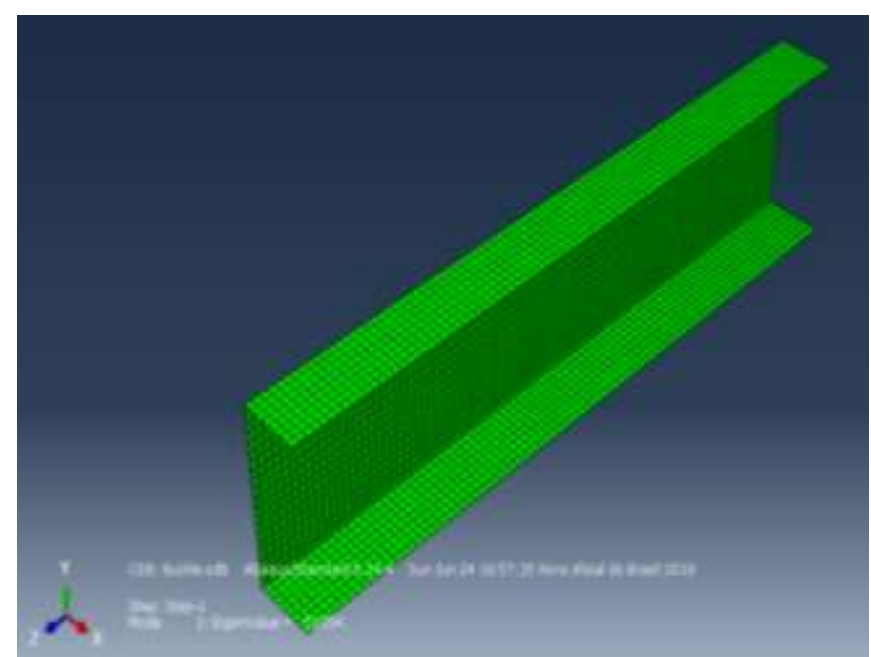

(b) Simplification of the model in ABAQUS

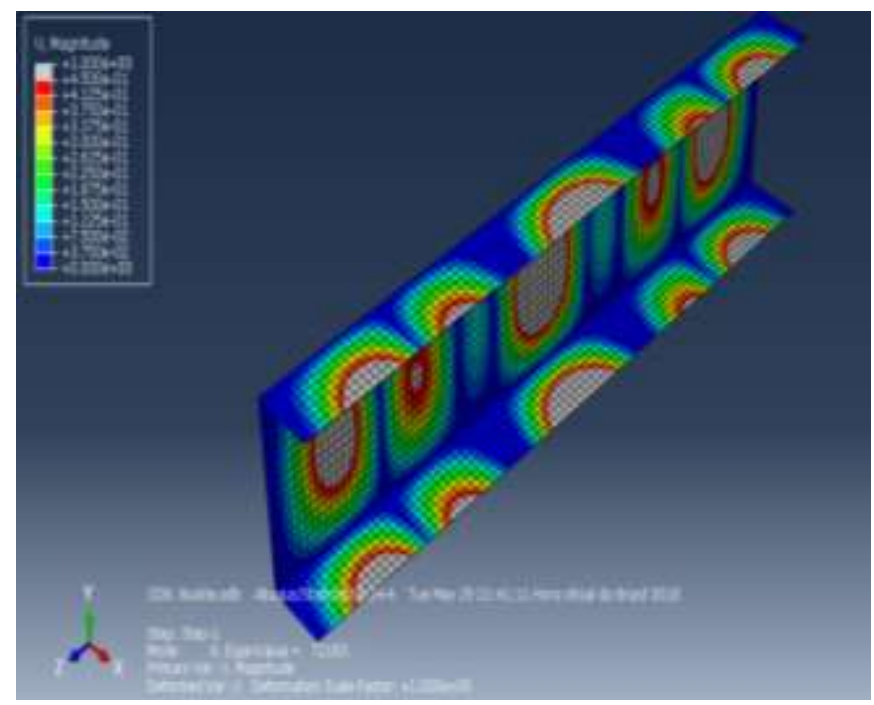

(c) Details of the first module of eigenvectors

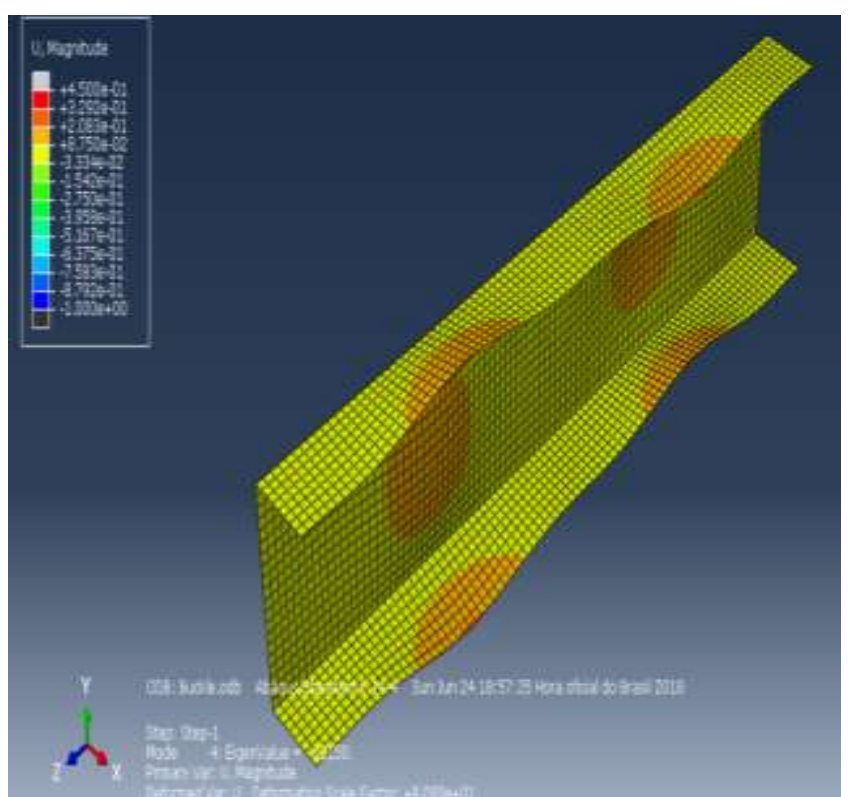

(d) Second module of eigenvectors

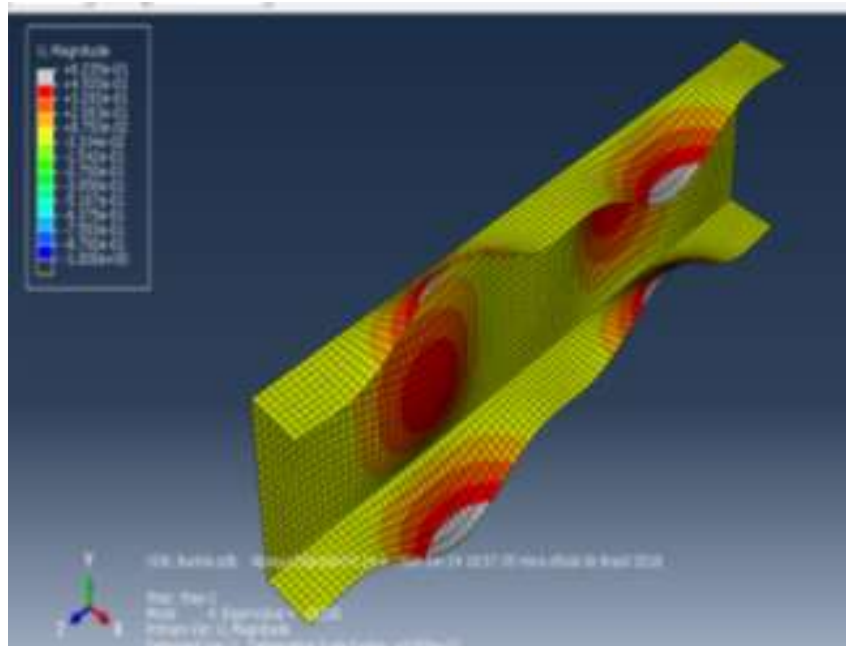

(e) Third eigenvector module

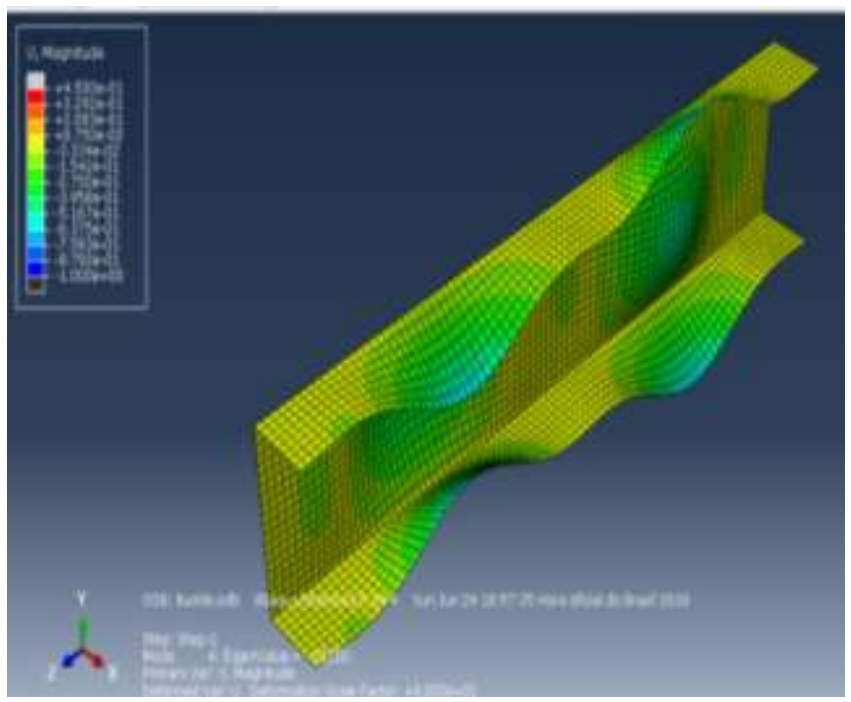

(f) Fourth module of eigenvectors 


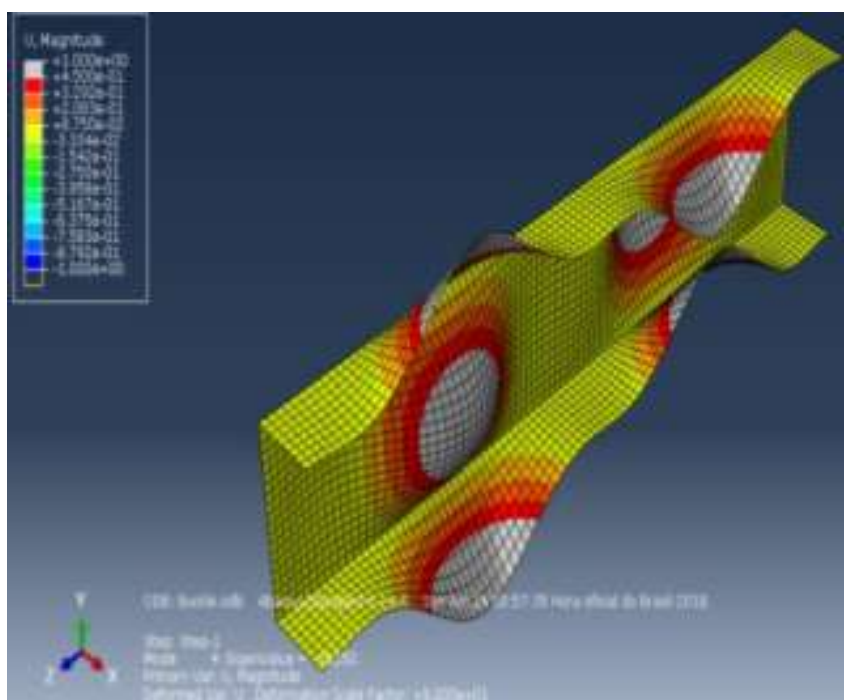

(g) Fifth module of eigenvectors

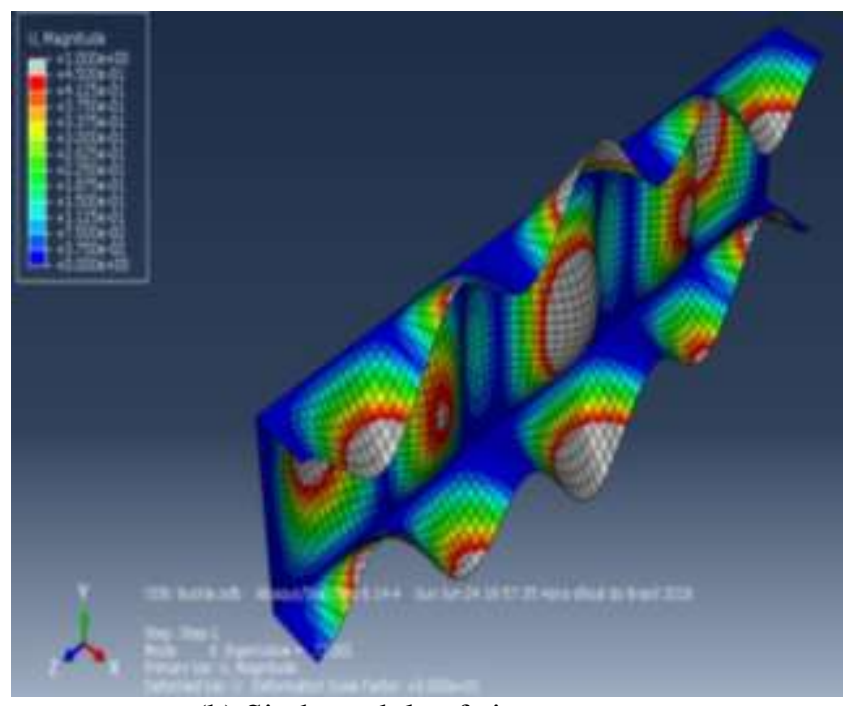

(h) Sixth module of eigenvectors

Fig 15: Numerical results through abaqus

Using the arc length method, the values were very close to the experimental result, as shown in Figure 15 in which the results were compared.
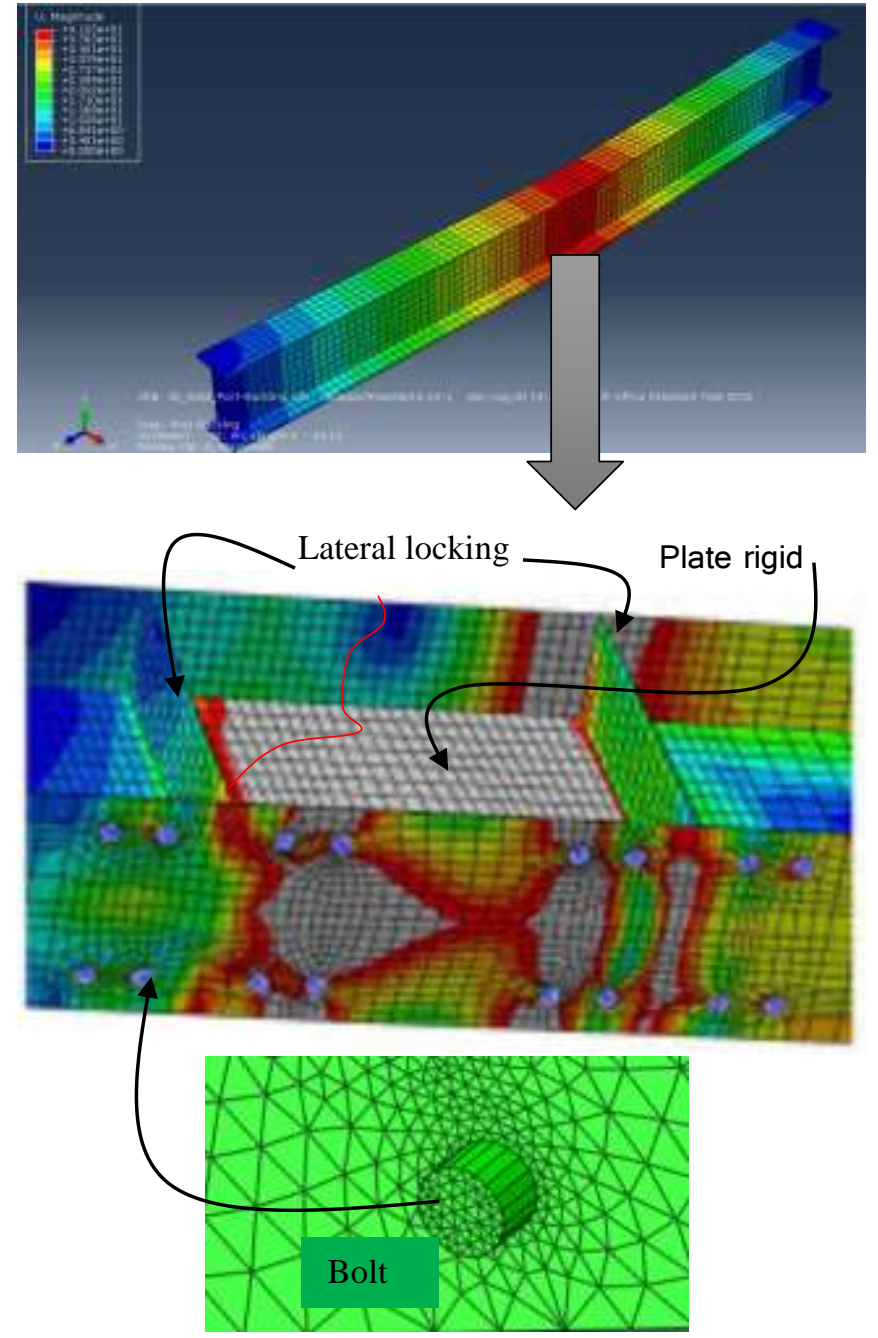

(a) Details of the numerical model in ABAQUS

The results of the tests are shown in Figure 16.The numerical model using ricks obtained results close to the experimental one with load of collapse of $127,2 \mathrm{kN}$ against $120 \mathrm{kN}$ of the experimental, that is to say, the numerical was with $6 \%$ error.

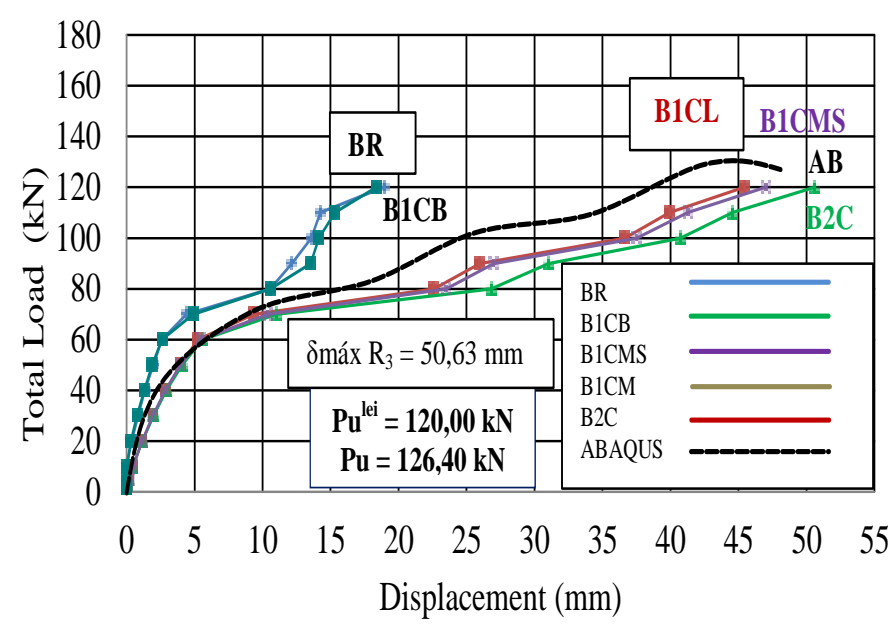

Fig 16: Comparison of ABAQUS versus experimental results 


\section{CONCLUSION}

The bonds of the bolted beams withstood the simple bending tests, and no rupture was found in the connection. Considerably, the beams with a bolted connection had bursting loads higher than the reference beams and the estimated values for the bursting load. In the beams with 2 and 3-point seams, the resistant capacity was lower than those with the one-point seam, because the welded regions did not coplanar.

The number of splices was not a collapsing factor for the beams nor influenced their rupture modes, but the way these splices were made may have influenced the collapse before the estimated. A better investigation of this is needed.

The analysis of the results of the lateral displacements showed that the lateral restraints in the supports played an important role in the reduction of these displacements when compared to the displacements of the beams with bolted connections.

The stud bolted beams had vertical displacements of tests higher than the theoretical values of calculation and also higher than those of reference joists, which had theoretical and test values very close, proving a higher stiffness in beams bolted. In the bolted beam, the screws were accommodated with the connecting plate and profile, which resulted in a greater vertical displacement.

No bolted connecting beam had ultimate load greater than the estimated ultimate load of calculation and were lower than most values found in welded joist beams, not because they were screwed, but because of the absence of lateral containments in the supports that caused collapse before expected. If it had these restraints, it would possibly reach the estimated ultimate load, since the values found in the tests were very close to the estimate.

All beams with bolted connections reached loads greater than $84 \mathrm{kN}$, which is the maximum service load for the reference beam. Therefore, the results of the tests showed that, if well executed, the screwed connections, with the specifications described in this work, can be used as connecting elements in the metallic structures, since there were no ruptures of these elements and, in addition, efforts.

The numerical model presented values very close to the experimental tests, showing the efficiency of the Ricks method implemented in ABAQUS.

\section{ACKNOWLEDGMENTS}

To the Federal University of Goiás, to CAPES for the financial support. To the Research Group in Structures and Civil Construction of the Federal University of Cariri GPEC and to the Post-Graduation Program in Civil Engineering CMEC of UFG.

\section{REFERENCES}

[1] ALMEIDA, A. Experimental analysis of beams consisting of cold formed profiles withwelds subjected to simple bending. 2009.Dissertation (Master in Civil Engineering) - School of Civil Engineering, Federal University of Goiás, Goiânia, 2009.

[2] AMERICAN WELDING SOCIETY. AWS A5.18 A5.18M:Specification for carbon steel electrodes and rods for gas shielded arc welding, Miami, 2005.

[3] BRAZILIAN ASSOCIATION OF TECHNICAL STANDARDS. NBR8800: Design of steel structures and mixed steel and concrete structures of buildings. Rio de Janeiro: 2008.

[4] BRAZILIAN ASSOCIATION OF TECHNICAL STANDARDS. NBR7007: Carbon steel and micro alloys for bars and hot-rolled sections for structural use. Rio de Janeiro: 2011.

[5] BRAZILIAN ASSOCIATION OF TECHNICAL STANDARDS. NBRISO 6892: Metallic materials: Tensile test. Rio de Janeiro: 2013.ASTM: AMERICAN SOCIETY FOR TESTING AND MATERIALS. Standard Specification for HighStrength Low-Alloy Columbium-Vanadium Structural Steel. ASTM A 572 / A 572M, West Conshohocken, 2006.

[6] CARDOSO, R. S. Study of the behavior of metal beams with "box" section, formed of profiles formed in the cold, with welded seams, submitted to simple bending. 2003. Dissertation (Master in Civil Engineering) - School of Civil Engineering, Federal University of Goiás, Goiânia, 2003.

[7] PEREIRA, R. S. Bonds in steel structures using splice seams with high strength screws required in simple bending. 2014. Dissertation (Master in Civil Engineering) - School of Civil Engineering, Federal University of Goiás, Goiânia, 2014.

[8] SILVA, T. D. A. Behavior study of metal beams in welded profile type "I", with welded seams, submitted to simple bending. 2007. Dissertation (Master in Civil Engineering) - School of Civil Engineering, Federal University of Goiás, Goiânia, 2007.

[9] VIEIRA, G. S. Experimental analysis of section I beams composed of cold formed profiles with welded seams subjected to simple bending. 2010. Dissertation (Master in Civil Engineering) - School of Civil Engineering, Federal University of Goiás, Goiânia, 2010.

[10] Salokhe S. A, Patil P., Comparative study of behaviour of cold-formed steeland hot rolled steel section under compressive loading. IJRET: International Journal of Research in Engineering and Technology, 2015.

\section{BIOGRAPHIES}




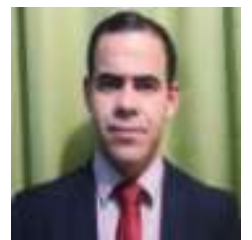

Master in Structures from the University of Brasilia-UnB. doctoral student in Structures by UnB. Areas of interest in the research: Finite Elements, Steel Structures, Structural Dynamics, Fracture Mechanics and Spatial Structure.

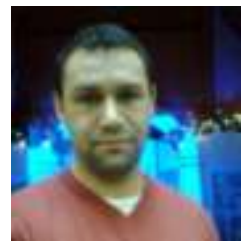

Doctorate in the Postgraduate Program in Structures and Civil Construction of the University of Brasília, Master in Civil Engineering from the Federal University of Goiás, Bachelor in Mechanical Engineering.

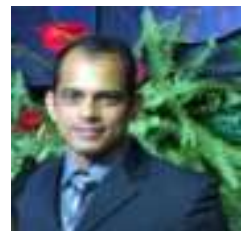

Doctorate in Structures and Civil Construction by the University of Brasília (2008). It acts on the following topics: stresses on bolts, prying action, contact stresses, t-stub connections, spatial structures, developing studies in threedimensional modeling, finite elements.

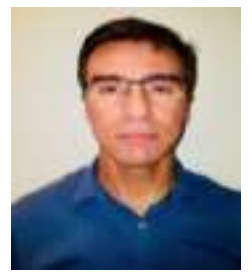

Master in Structures and Civil Construction by the University of Brasília and Doctorate in Structures and Civil Construction by the University of Brasília (2006). He is currently professor of the Federal Institute of Education, Science and Technology of Goiás, in the areas of Positioning by Satellites and Metallic Structures. 